\title{
Phosphorylated KDR expression in endometrial cancer cells relates to HIF1 $\alpha /$ VEGF pathway and unfavourable prognosis
}

\author{
Alexandra Giatromanolaki ${ }^{1}$, Michael I Koukourakis ${ }^{2}$, Helen Turley ${ }^{3}$, Efthimios Sivridis ${ }^{1}$, \\ Adrian L Harris ${ }^{4}$ and Kevin C Gatter ${ }^{3}$, for the 'Tumour and Angiogenesis Research Group' \\ ${ }^{1}$ Department of Pathology, Democritus University of Thrace Medical School, Alexandroupolis, Greece; \\ ${ }^{2}$ Department of Radiotherapy/Oncology, Democritus University of Thrace Medical School, Alexandroupolis, \\ Greece; ${ }^{3}$ Department of Pathology, Nuffield Department of Clinical Laboratory Sciences, John Radcliffe \\ Hospital, Oxford, UK and ${ }^{4}$ Cancer Research UK, Molecular Oncology Laboratories, Institute of Molecular \\ Medicine, John Radcliffe Hospital, Oxford, UK
}

\begin{abstract}
Vascular endothelial growth factor (VEGF) is a potent angiogenic factor for many malignant neoplasms exerting its function through activation of specific membrane receptors, that is, KDR/flk-1, residing in endothelial cells. Several recent reports indicate that VEGF receptors are also expressed in cancer cells, suggesting that specific VEGF-originated cancer cell reactions may parallel the endothelial response. Using a novel monoclonal antibody, recognizing the activated (phosphorylated) form of the KDR receptor (pKDR), we assessed the expression of pKDR in normal and malignant endometrium. A strong and consistent cytoplasmic and nuclear pKDR expression was noted in the normally cycling endometrium, including epithelial, stromal and endothelial cells, suggesting a role in the normal menstrual cycle. Approximately, one-third of the 70 stage I endometrioid adenocarcinomas analysed exhibited an intense cytoplasmic and nuclear pKDR expression in both cancer cells and peritumoral vessels. It was noted that such pKDR reactivity in cancer cells was related directly to VEGF, VEGF/KDR complexes and HIF1 $\alpha$ (hypoxia inducible factor $1 \alpha$ ) expression. Furthermore, pKDR expression was significantly associated with poor prognosis. It is concluded that the VEGF/KDR pathway is activated in both normally cycling and malignant endometrium, suggestive of an important role in the biology of this tissue. The unfavourable prognosis that VEGF confers to endometrial adenocarcinomas could be attributed to its angiogenic activity, but also to a direct effect on cancer cells through an autocrine VEGF/KDR loop.

Modern Pathology (2006) 19, 701-707. doi:10.1038/modpathol.3800579; published online 24 March 2006
\end{abstract}

Keywords: endometrial adenocarcinoma; phosphorylation; KDR; VEGF; HIF1 $\alpha$

Vascular endothelial growth factor (VEGF) is a heparin-binding growth factor that promotes endothelial cell proliferation and affects survival. ${ }^{1,2}$ It acts on specific tyrosine kinase receptors, VEGFR-1 (flt-1), VEGFR-2 (KDR/flk-1) and VEGFR-3 (flt-4). Although these molecules are predominantly expressed on endothelial cells, the VEGFR-1 receptor has also been identified in trophoblastic cells, renal mesangial cells and monocytes, while VEGFR-2 expression has been detected in haematopoietic stem cells and megakaryocytes..$^{3-6}$ Both receptors are glycosylated and, in this form, undergo phos-

Correspondence: Dr A Giatromanolaki, MD, Department of Pathology, Democritus University of Thrace Medical School, PO Box 12, Alexandroupolis 68100, Greece.

E-mail: targ@her.forthnet.gr

Received 21 December 2005; revised 31 January 2006; accepted 5 February 2006; published online 24 March 2006 phorylation, in response to VEGF, which is an important step in the signalling of VEGF.,8

Cancer cells and intratumoral endothelium have also been reported to express VEGF receptors. ${ }^{9-13}$ The expression of VEGFRs, however, does not necessarily mean active participation in cancer or endothelial cell biology as this can only be analysed by assessing the activated forms of these receptors. Brekken et $a 1^{14}$ produced monoclonal antibodies that preferentially recognize VEGF bound to its receptor KDR, which presumably reflects the activated KDR receptor. Indeed, expression of VEGF/ KDR complexes were noted in cancer cells and intratumoral vasculature in lung and endometrial carcinomas and this feature was significantly related to prognosis and increased vascular density at the invading tumour front. ${ }^{15,16}$

Recently, specific monoclonal antibodies have been raised against the phosphorylated (activated) 
form of KDR (pKDR) by our group. ${ }^{17,18}$ In the current study, we used one of these antibodies to investigate the expression of the $\mathrm{pKDR}$ receptor in normal and malignant endometrium. Association with histopathological features, angiogenesis, hypoxiaregulated proteins and patients' prognosis was also assessed.

\section{Materials and methods}

We examined 70 tumour samples from patients with stage I endometrioid adenocarcinomas, and 20 samples from normally cycling endometrium of both proliferative and secretory phase. Formalinfixed, paraffin-embedded material was retrieved from the archives of the Department of Pathology, Democritus University of Thrace Medical School, Alexandroupolis, Greece. All patients had been treated surgically with total abdominal hysterectomy and bilateral salpingo-oophorectomy. No lymph node sampling of the iliac nodes was performed, and N-staging was based on pelvic and abdominal CT scan. Histological typing and grading of the endometrial tumours (grade 1 vs grades 2 and 3$)$ and the depth of myometrial invasion $(<1 / 2$ vs $>1 / 2$ ) were assessed on haematoxylin-eosin sections, using standard criteria. ${ }^{19,20}$ Lymphaticvascular space invasion was recorded as being present if tumour cells were seen within a space with a definite and clearly identifiable endothelial lining. The follow-up of patients ranged from 6 to 170 months with a mean of 66 months. For patients alive at the time of analysis (61/70 patients), the median follow-up was 70 months (range 22-176).

\section{Immunohistochemistry for pKDR}

The pKDR protein was assessed using monoclonal antibody 34a raised against the Y1214 tyrosine residue of the KDR protein. ${ }^{17}$

Sections were deparaffinised and peroxidase was quenched with methanol and $\mathrm{H}_{2} \mathrm{O}_{2} 3 \%$ for $15 \mathrm{~min}$. Thereafter, slides were placed in antigen unmasking buffer, pH 6.0 (code: TAR001, ILEM, Italy) and microwaving followed $(3 \times 4 \mathrm{~min})$. The primary antibody (supernatant dilution 1:2) was applied overnight, at room temperature. Following washing with TBS, sections were incubated with a secondary mouse anti-rabbit antibody (Kwik Biotinylated Secondary, 0.69A Shandon-Upshaw, Pittsburgh, PA, USA) for $15 \mathrm{~min}$ and washed in TBS. Kwik Streptavidin peroxidase reagent (039A Shandon-Upshaw, Pittsburgh, PA, USA) was applied for $15 \mathrm{~min}$ and sections were again washed in TBS. The colour developed by 15 min of incubation with DAB solution and sections were weakly counterstained with haematoxylin. Normal kidney sections were used as positive controls. ${ }^{18}$ Normal immunoglobulin-G was substituted for the primary antibody as the negative control, at a concentration where immunostaining of control slides gave a faint cytoplasmic staining.

The percentage of cancer cells with cytoplasmic and nuclear pKDR reactivity was recorded separately after inspection of all fields in the tissue sample. The percentage of positive cells was recorded in each individual field and the median value obtained for each case was the final score.

\section{Other Immunohistochemistry}

Table 1 shows the antibodies and details of the immunohistochemical procedures used to detect the expression of various oncoproteins and growth factors/receptors. Extensive reports of the methods used have been published previously. ${ }^{16,21-23}$

The assessment of HIF $1 \alpha$ and $2 \alpha$ expression was performed according to an HIF grading system reported previously. ${ }^{21}$ Scoring the expression of VEGF/KDR complexes, VEGF and TP were based on assessing the percentage of cancer cells with cytoplasmic VEGF/KDR or VEGF expression and nuclear TP expression, following examination of the whole tumour area at $\times 200$ magnification. ${ }^{16,22}$ The median value was used to score cases with low or high reactivity. A $10 \%$ cancer cell positivity was required to score a case as positive for bcl-2 protein cytoplasmic expression, p53 protein nuclear accumulation and nuclear oestrogen (ER) and progester-

Table 1 Details of the antibodies, dilutions and antigen retrieval methods used in this study

\begin{tabular}{|c|c|c|c|c|c|}
\hline Primary antibody & Dilution/incubation time & Antigen retrieval & Specificity & Source & Reference \\
\hline JC70 (CD31) & $1: 50\left(60 \min ^{\mathrm{a}}\right)$ & Protease XXIV & Endothelium & Dako, Denmark & Giatromanlaki et $a l^{16}$ \\
\hline ESEE 122 & $1: 20\left(90 \min ^{\mathrm{a}}\right)$ & MW & HIF- $1 \alpha$ & Oxford University & Sivridis et $a l^{19}$ \\
\hline EP 190b & Neat $\left(90 \mathrm{~min}^{\mathrm{a}}\right)$ & MW & $\mathrm{HIF}-2 \alpha$ & Oxford University & Sivridis et $a l^{19}$ \\
\hline VG1 & 1:4 (90 $\left.\min ^{\mathrm{a}}\right)$ & MW & VEGF & Oxford University & Sivridis and Giatromanlaki ${ }^{20}$ \\
\hline 11B5 & $1: 3\left(60 \min ^{\mathrm{a}}\right)$ & MW & VEGF/KDR & Texas University & Giatromanlaki $^{16}$ \\
\hline P-GF.44C & $1: 4\left(60 \mathrm{~min}^{\mathrm{a}}\right)$ & No & $\mathrm{TP}$ & Oxford University & Sivridis and Giatromanlaki ${ }^{20}$ \\
\hline DO-7 & $1: 30$ overnight at $4^{\circ} \mathrm{C}$ & MW & p53 & Dako & Sivridis et $a l^{21}$ \\
\hline 124 & $1: 80$ overnight at $4^{\circ} \mathrm{C}$ & MW & bcl-2 & Dako & Sivridis et $a l^{21}$ \\
\hline 1D5 & $1: 100\left(60 \min ^{\mathrm{a}}\right)$ & MW & ER & Immunon-Shandon & Sivridis et al ${ }^{19}$ \\
\hline $1 \mathrm{~A} 6$ & 1:100 $\left(60 \mathrm{~min}^{\mathrm{a}}\right)$ & MW & PgR & Immunon-Shandon & Sivridis et $a l^{19}$ \\
\hline
\end{tabular}

MW = microwave heating

${ }^{\mathrm{a}}$ At room temperature. 
one (PgR) receptor reactivity, which are the generally accepted cutoff points for these antibodies. ${ }^{21,23}$

Microvessel counting was used for angiogenesis assessment. Sections were scanned at low power and afterwards at $\times 200$ fields in order to group cases into three categories (low, medium and high). Areas at the invading tumour edge of the highest vascularization were chosen at low power $(\times 100)$ and microvessel counting followed on three chosen $\times 200$ fields of the highest density. The vascular density (VD) was the mean of the vessel counts obtained in these three fields. Vessels with a clearly defined lumen or well-defined linear vessel shape but not single endothelial cells were taken into account for microvessel counting. The median value was used to define two groups of low and high VD. ${ }^{16}$

\section{Statistical Analysis}

Statistical analysis and graphic presentation were performed using the GraphPad Prism ${ }^{\circledR} 4.0$ package and the Instat ${ }^{\circledR} 3.0$ packages (GraphPad, San Diego CA, www.graphpad.com). The Fisher's exact test, the chi-square $t$-test or the unpaired two-tailed $t$-test was used for testing relationships between categorical variables as appropriate. Spearman analysis was used to assess correlation between continues variables. Survival curves were plotted using the method of Kaplan-Meier, and the log-rank test was used to determine statistical differences between life tables. A Cox proportional hazard model was used to assess the effects of patient and tumour variables on overall survival. A $P$-value $<$ or equal to 0.05 was considered significant.

\section{Results}

\section{pKDR in the Normal Endometrium}

pKDR was expressed strongly in the normally cycling endometrium. The staining was both cytoplasmic and nuclear in the glandular epithelial cells and extended throughout the menstrual cycle (Figure 1a). The stromal cells showed only nuclear reactivity; this was limited only to the functional layer during the proliferative phase but involved uniformly the basal and functional layers in the secretory phase endometrium. The myometrial cells showed strong cytoplasmic positivity. The endothelium showed cytoplasmic and nuclear pKDR expression in all uterine coats: endometrium, myometrium and perimetrium (Figure 1b). Lymphatic vessels of the myometrium were also strongly reactive.

\section{pKDR in Endometrial Cancer}

Strong cytoplasmic reactivity was noted in 27/70 endometrial carcinoma cases (Figure 1c); the reaction ranged from 20 to $80 \%$ (median $55 \%$ ) in cancer cells. In $8 / 27$ cases with cytoplasmic posi- tivity, nuclear pKDR reactivity was also noted in $>10 \%$ of the neoplastic nuclei (Figure 1d).

Expression of pKDR was also noted in rather larger peritumoral vessels, mainly at the invading tumour front (Figure 1e), while very small immature blood capillaries were negative.

\section{Correlation with Histopathological Variables}

Table 2 shows the relation of pKDR expression with histological variables and hormone receptor status. There was no association with histological grade and depth of myometrial invasion, while a marginal association with nuclear expression of progesterone receptors was noted.

\section{Correlation with Molecular Variables and VD}

Table 3 shows the association of pKDR expression with angiogenesis, hypoxia-inducible factors and oncoprotein expression. pKDR was directly linked with HIF $1 \alpha$ and VEGF expression $(P=0.01$ and 0.001 , respectively). A strong association of $\mathrm{pKDR}$ expression with the expression of the VEGF/KDR complex in the cytoplasm of cancer cells was noted. No association with HIF $2 \alpha$, vascular density, TP, p53 and bcl-2 protein expression was noted.

\section{Survival Analysis}

Overall, nine patients died during the follow-up of patients, corresponding to a $12.8 \%$ death rate. The death rates were $2 / 43(4.6 \%)$ and $7 / 27(25.9 \%)$ in cases with high and low pKDR expression, respectively $(P=0.02)$. Out of the traditional histology prognostic features, histology grade was the most important in death rate analysis (the death rates were $4 / 55(7.2 \%)$ for grade 1 vs $3 / 15(20 \%)$ for grade $2 / 3$ cases; $P=0.16)$.

Survival analysis according to Kaplan-Meier showed a significant association of pKDR expression in cancer cells with poor overall survival $(P=0.009)$ in stage I endometrial cancer patients (Figure 2a). Figure $2 \mathrm{~b}$ shows that the significant worse prognosis of patients with high pKDR expression is also maintained in the group of patients with grade 1 histology. In multivariate analysis (Table 4) taking into account the pKDR and the histological variables, pKDR was a strong and independent marker of prognosis $(P=0.007$, risk ratio 2.75). Taking all parameters into account, HIF $1 \alpha$ and histology grade were also independently linked with prognosis.

\section{Discussion}

VEGF is a potent angiogenic growth factor promoting endothelial cell proliferation and new blood vessel formation; ${ }^{1,2}$ its expression in cancer cells has been associated with increased vascular density and unfavourable survival in a variety of malignant 

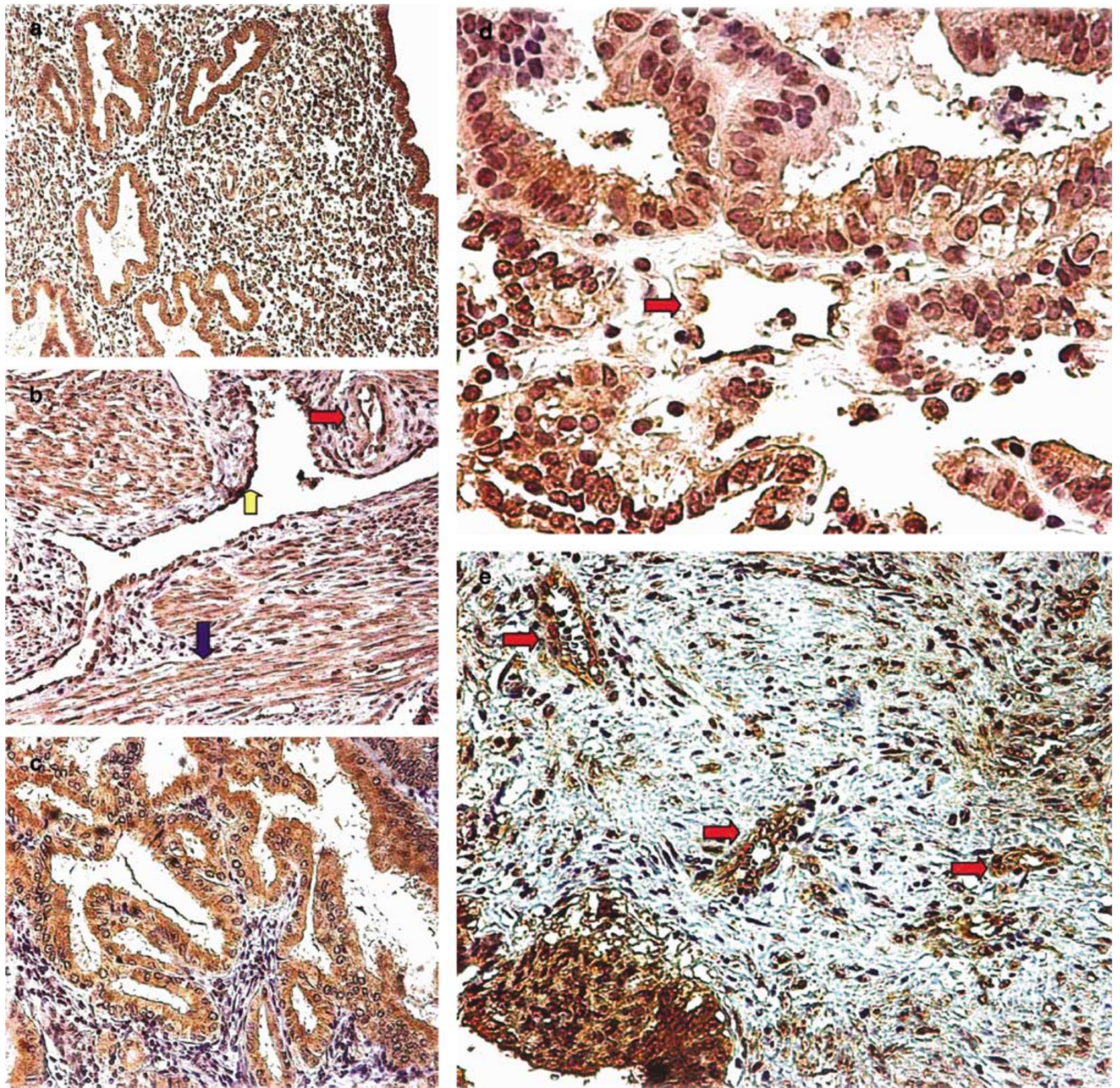

Figure 1 pKDR expression in normal and neoplasic endometrium: (a) pKDR cytoplasmic and nuclear expression in normal proliferating endometrium and stroma cells. (b) pKDR expression in normal myometrium (blue arrow) and related lympatics (yellow arrow) and vessels (red arrow). (c) Cytoplasmc pKDR expression in endometrioid cancer. (d) pKDR nucelar expression in endometrioid cancer and intratumoral vessel (red arrow). (e) pKDR expression in tumour-related vasculature in the invading tumour edge (red arrows).

tumours. Such a relation between VEGF expression, angiogenesis and prognosis was reported by us previously in patients with endometrial cancer. ${ }^{22}$ Using a monoclonal antibody, recognizing the VEGF/KDR complexes, we also verified overexpression in cancer cells and in capillary endothelium located at the invading tumour edge. ${ }^{16}$ Cancer cell reactivity was thought to represent VEGF content, as KDR was thought to be confined to endothelial cells, despite reports suggesting the presence of KDR in a variety of human tumours, including breast, lung and endometrial carcinomas. ${ }^{9-13}$ Constitutive ex- pression of KDR, however, may not necessarily mean an active KDR pathway.

It was only recently that monoclonal antibodies were raised against the phosphorylated form of KDR allowing reconsideration of the role of KDR in tissues. ${ }^{17,18}$ The wide distribution of pKDR in normal and malignant epithelial cells and its expression in both cytoplasm and nuclei stressed the importance of the VEGF/KDR pathway in epithelial cell biology.

In this study, we examined the expression of the phosphorylated (activated) KDR receptor in normal 
Table 2 Association of pKDR expression with histological parameters and hormone receptor expression in endometrial adenocarcinomas

\begin{tabular}{|c|c|c|c|}
\hline & \multicolumn{2}{|c|}{$p K D R$} & \multirow[t]{2}{*}{ P-value } \\
\hline & Low & High & \\
\hline \multicolumn{4}{|c|}{ Histological grade } \\
\hline 1 & 33 & 22 & 0.76 \\
\hline 2,3 & 10 & 5 & \\
\hline \multicolumn{4}{|c|}{ Myometrial depth invasion } \\
\hline$<1 / 2$ & 23 & 13 & 0.80 \\
\hline$>1 / 2$ & 20 & 14 & \\
\hline \multicolumn{4}{|l|}{$E R$} \\
\hline Low & 35 & 20 & 0.77 \\
\hline High & 9 & 7 & \\
\hline \multicolumn{4}{|l|}{$P g R$} \\
\hline Low & 35 & 21 & 0.08 \\
\hline High & 8 & 6 & \\
\hline
\end{tabular}

ER, oestrogen receptor; PgR, progesterone receptor; pKDR, phosphorylated form of the KDR.

Table 3 Association of pKDR expression with molecular variables expressed in endometrial cancer cells

\begin{tabular}{|c|c|c|c|}
\hline & \multicolumn{2}{|c|}{$p K D R$} & \multirow[t]{2}{*}{ P-value } \\
\hline & Low & High & \\
\hline \multicolumn{4}{|l|}{$H I F 1 \alpha$} \\
\hline Low & 28 & 9 & 0.01 \\
\hline High & 15 & 18 & \\
\hline \multicolumn{4}{|l|}{$H I F 2 \alpha$} \\
\hline Low & 37 & 20 & 0.22 \\
\hline High & 6 & 7 & \\
\hline \multicolumn{4}{|l|}{$V E G F$} \\
\hline Low & 30 & 8 & 0.001 \\
\hline High & 13 & 19 & \\
\hline \multicolumn{4}{|c|}{$V E G F / K D R$} \\
\hline Low & 33 & 5 & $<0.0001$ \\
\hline High & 10 & 22 & \\
\hline \multicolumn{4}{|c|}{ VD invading front } \\
\hline Low & 23 & 12 & 0.62 \\
\hline High & 20 & 15 & \\
\hline \multicolumn{4}{|c|}{ TP nuclear } \\
\hline Low & 34 & 21 & 0.99 \\
\hline High & 9 & 6 & \\
\hline \multicolumn{4}{|l|}{ Mut-p53 } \\
\hline Low & 41 & 25 & 0.63 \\
\hline High & 2 & 2 & \\
\hline \multicolumn{4}{|l|}{ Bcl-2 } \\
\hline Low & 29 & 19 & 0.99 \\
\hline High & 14 & 8 & \\
\hline
\end{tabular}

ER, oestrogen receptor; PgR, progesterone receptor; pKDR, phosphorylated form of the KDR; VEGF, vascular endothelial growth factor; VD, vascular density; HIF $2 \alpha$, hypoxia-inducible factor $1 \alpha$.

and malignant endometrial tissues. pKDR was consistently expressed in the normal endometrium throughout the menstrual cycle. The subcellular
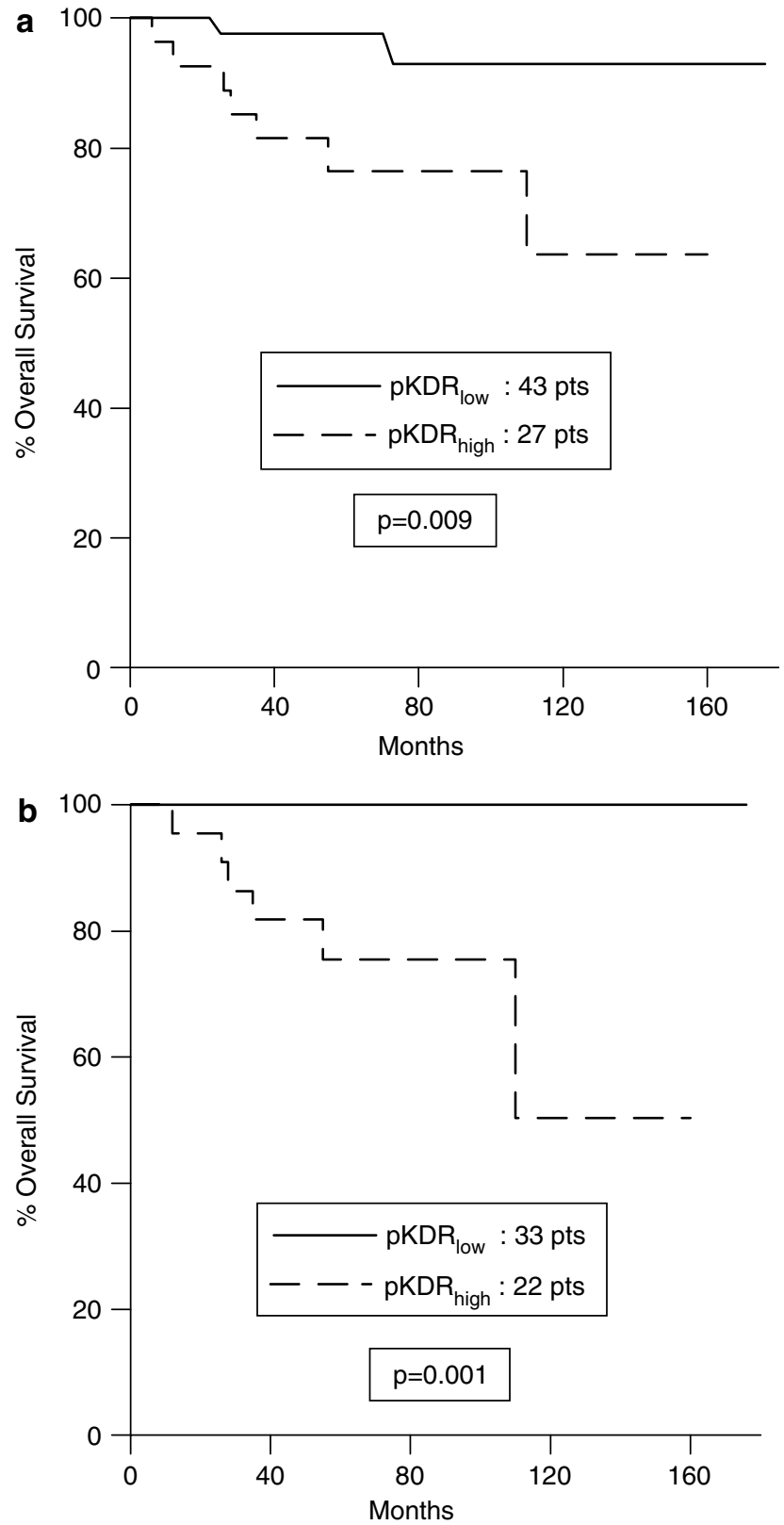

Figure 2 Kaplan-Meier survival curves stratified for pKDR expression in endometrial cancer cells (a, all cases; b, cases with grade histology).

localization indicated a cytoplasmic and nuclear shift of the activated receptor. The cyclic expression of pKDR in the stromal cells of the basal layer of the endometrium (switched on in the secretory and off in the proliferative phase) shows that the VEGF/KDR pathway may have a role in the cyclic regeneration and degeneration of the normal endometrium. VEGF is expressed in normal endometrial stromal cells, an expression that appears to be increased in the presence of ovarian steroids, ${ }^{24,25}$ specifically progesterone, as suggested in the current study.

Expression of pKDR was also observed in the cytoplasm and nuclei of endometrial cancer cells in 
Table 4 Multivariate analysis of death events taking into account all histological and molecular variables studied (Model 1) or pKDR and morphological variables alone (Model 2)

\begin{tabular}{lccccc}
\hline \multirow{2}{*}{ Variable } & \multicolumn{2}{c}{ Model 1 } & & \multicolumn{2}{c}{ Model 2 } \\
\cline { 2 - 3 } \cline { 5 - 6 } & t-ratio & P-value & & t-ratio & P-value \\
& & & & & \\
\hline pKDR & 1.12 & 0.26 & & $\mathbf{2 . 7 5}$ & $\mathbf{0 . 0 0 7}$ \\
Grade & $\mathbf{2 . 1 4}$ & $\mathbf{0 . 0 3}$ & & 1.16 & 0.24 \\
Depth & 1.64 & 0.10 & & 0.75 & 0.45 \\
Vasc. invas. & 1.46 & 0.14 & & 0.54 & 0.59 \\
HIF1 $\alpha$ & $\mathbf{2 . 0 9}$ & $\mathbf{0 . 0 4}$ & & - & - \\
HIF2 $\alpha$ & 0.65 & 0.51 & & - & - \\
VEGF & 1.54 & 0.12 & & - & - \\
VD & 1.70 & 0.09 & & - & - \\
p53 & 0.71 & 0.47 & & - & - \\
bcl-2 & 0.34 & 0.72 & & - & - \\
PgR & 0.24 & 0.80 & - & - \\
ER & 1.59 & 0.11 & - & - \\
\hline
\end{tabular}

ER, oestrogen receptor; PgR, progesterone receptor; pKDR, phosphorylated form of the KDR; VEGF, vascular endothelial growth factor; VD, vascular density; HIF $2 \alpha$, hypoxia-inducible factor $1 \alpha$.

The statistically significant values are in bold.

approximately $30 \%$ of the cases analysed. This paralleled the expression of the VEGF/KDR complexes in the cancer cell cytoplasm, indicating that KDR is not simply expressed in endometrial cancer cells but also participates actively in the biology of this neoplasm. A direct association between the expression of pKDR and VEGF is noted, suggestive of an autocrine loop, where cancer cells by secreting VEGF activate a KDR signalling pathway. The existence of such an autocrine mechanism has been also suggested previously in a number of studies. ${ }^{26-29}$ Whether such an autocrine loop functions as a stimulus for cancer cell proliferation, resistance to apoptotic stimuli or through some other process remains obscure. ${ }^{30-33}$ Nevertheless, expression of pKDR was associated significantly with poor prognosis of stage I patients. Histological grade was also a significant independent variable of prognosis, while depth of myometrial invasion and lympho-vascular space invasion did not reach significance. The finding that $\mathrm{pKDR}$ expression defined a group of poor prognosis even in the grade 1 cases supports the suggestion that the VEGF/KDR route contributes to the development of a particularly aggressive endometrial tumour phenotype. This is probably achieved by two main pathways: (a) manipulation of cancer cell behaviour through autocrine cancer cell routes and, (b) accentuation of the angiogenic process (as previously shown. ${ }^{16,22}$ )

The concurrent expression of pKDR and HIF $1 \alpha$ in many endometrial adenocarcinomas could be a direct result of VEGF upregulation by HIF1 $\alpha$ and subsequent activation of KDR. Yet, a functional association of HIF1 $\alpha$ with KDR upregulation cannot be entirely excluded. Gerber et $a l^{34}$ showed that, in contrast to the flt-1 receptor, KDR is not induced by hypoxia. However, this finding contrasts to Waltenberger et al's ${ }^{35}$ earlier report, where hypoxia upregulated the expression of KDR in the endothelial cells of umbilical veins. Upregulation of VEGF and KDR, which is paralleled by HIF $1 \alpha$ expression, has also been recorded in rabbit skeletal muscle during acute hypoxia. ${ }^{36} \mathrm{KDR}$ is also induced by hypoxia in choroid-retinal endothelial (RF/6A) cells. ${ }^{37}$ In any case, the co-expression of pKDR with the HIF $1 \alpha$ downstream genes may be an additional reason for the unfavourable prognosis noted in tumours with pKDR expression. The nuclear role of pKDR need further evaluation, but a nuclear role for other tyrosine kinase receptors (ie erbB4) has recently been shown. ${ }^{38}$

It is concluded that the VEGF/KDR pathway, in contrast to previous beliefs, is activated in the normally cycling endometrium and in more than $30 \%$ of endometrial adenocarcinomas, suggesting an important role in the biology of normal endometrium and endometrial neoplasia. The unfavourable prognosis of VEGF-expressing endometrial carcinomas could be attributed both to the angiogenic activity of the factor and its direct effect on cancer cells, probably through an autocrine VEGF/ KDR mechanism. Specific therapies targeting KDR phosphorylation (anti-VEGF monoclonal antibodies or tyrosin kinase inhibitors) may therefore posses a dual activity both by suppressing angiogenesis and by interfering with the biology of cancer cells.

\section{Acknowledgements}

The study was financially supported by the Cancer Research UK and the Tumour and Angiogenesis Research Group.

\section{References}

1 Neufeld G, Cohen T, Gengrinovitch S, et al. Vascular endothelial growth factor (VEGF) and its receptors. FASEB J 1999;13:9-22.

2 Klagsbrun M, D'Amore PA. Vascular endothelial growth factor and its receptors. Cytokine Growth Factor Rev 1996;7:259-270.

3 Charnockjones DS, Sharkey AM, Boocock CA, et al. Vascular endothelial growth factor receptor localization and activation in human trophoblast and choriocarcinoma cells. Biol Reprod 1994;51:524-530.

4 Takahashi T, Shirasawa T, Miyake K, et al. Protein tyrosine kinases expressed in glomeruli and cultured glomerular cells: FLT-1 and VEGF expression in renal mesangial cells. Biochem Biophys Res Commun 1995;209:218-226.

5 Katoh O, Tauchi H, Kawaishi K, et al. Expression of the vascular endothelial growth factor (VEGF) receptor gene, KDR, in hematopoietic cells and inhibitory effect of VEGF on apoptotic cell death caused by ionizing radiation. Cancer Res 195;55:5687-5692.

6 Katoh O, Tauchi H, Kawaishi K, et al. Expression of the vascular endothelial growth factor (VEGF) receptor gene, KDR, in hematopoietic cells and inhibitory effect of VEGF on apoptotic cell death caused by ionizing radiation. Cancer Res 1995;55:5687-5692. 
7 Takahashi T, Shibuya M. The $230 \mathrm{kDa}$ mature form of KDR/Flk-1 (VEGF receptor-2) activates the PLCgammaN pathway and partially induces mitotic signals in NIH3T3 fibroblasts. Oncogene 1997;14:2079-2089.

8 Quinn TP, Peters KG, De Vries C, et al. Fetal liver kinase 1 is a receptor for vascular endothelial growth factor and is selectively expressed in vascular endothelium. Proc Natl Acad Sci USA 1993;90:7533-7537.

9 Gitay-Goren H, Halaban R, Neufeld G. Human melanoma cells but not normal melanocytes express vascular endothelial growth factor receptors. Biochem Biophys Res Commun 1993;190:702-709.

10 Mentlein R, Forstreuter F, Mehdorn HM, et al. Functional significance of vascular endothelial growth factor receptor expression on human glioma cells. J Neurooncol 2004;67:9-18.

$11 \mathrm{Wu} \mathrm{W}$, Shu X, Hovsepyan $\mathrm{H}$, et al. VEGF receptor expression and signaling in human bladder tumors. Oncogene 2003;22:3361-3370.

12 Speirs V, Atkin SL. Production of VEGF and expression of the VEGF receptors Flt-1 and KDR in primary cultures of epithelial and stromal cells derived from breast tumours. Br J Cancer 1999;80:898-903.

13 Decaussin M, Sartelet H, Robert C, et al. Expression of vascular endothelial growth factor (VEGF) and its two receptors (VEGF-R1-Flt1 and VEGF-R2-Flk1/KDR) in non-small cell lung carcinomas (NSCLCs): correlation with angiogenesis and survival. J Pathol 1999; 188:369-377.

14 Brekken RA, Overholser JP, Stastny VA, et al. Selective inhibition of vascular endothelial growth factor (VEGF) receptor 2 (KDR/Flk-1) activity by a monoclonal anti-VEGF antibody blocks tumor growth in mice. Cancer Res 2000;60:5117-5124.

15 Koukourakis MI, Giatromanolaki A, Thorpe PE, et al. Vascular endothelial growth factor/KDR activated microvessel density versus CD31 standard microvessel density in non-small cell lung cancer. Cancer Res 2000;60:3088-3095.

16 Giatromanolaki A, Sivridis E, Brekken R, et al. Tumour Angiogenesis Research Group. The angiogenic 'vascular endothelial growth factor/flk-1(KDR) receptor' pathway in patients with endometrial carcinoma: prognostic and therapeutic implications. Cancer 2001; 92:2569-2577.

17 Stewart M, Turley H, Cook N, et al. The angiogenic receptor KDR is widely distributed in human tissues and tumours and relocates intracellularly on phosphorylation. An immunohistochemical study. Histopathology 2003;43:33-39.

18 Fox SB, Turley H, Cheale M, et al. Phosphorylated KDR is expressed in the neoplastic and stromal elements of human renal tumours and shuttles from cell membrane to nucleus. J Pathol 2003;202: 313-320.

19 Sivridis E, Fox H, Buckley CH. Endometrial carcinoma: two or three entities? In J Gynecol Cancer 1998;8:183-188.

20 Sivridis E, Giatromanolaki A. Prognostic aspects on endometrial hyperplasia and neoplasia. Virchows Arch 2001;439:118-126.

21 Sivridis E, Giatromanolaki A, Gatter KC, et al., Tumor and Angiogenesis Research Group. Association of hypoxia-inducible factors 1alpha and 2alpha with activated angiogenic pathways and prognosis in patients with endometrial carcinoma. Cancer 2002; 95:1055-1063.
22 Sivridis E, Giatromanolaki A, Anastasiadis P, et al. Tumour and Angiogenesis Research Group. Angiogenic co-operation of VEGF and stromal cell TP in endometrial carcinomas. J Pathol 2002;196:416-422.

23 Giatromanolaki A, Sivridis E, Koukourakis MI, et al. Bcl-2 and p53 expression in stage I endometrial carcinoma. Anticancer Res 1998;18:3689-3693.

24 Kapiteijn K, Koolwijk P, Van Der Weiden R, et al. Steroids and cytokines in endometrial angiogenesis. Anticancer Res 2001;21:4231-4242.

25 Lebovic DI, Shifren JL, Ryan IP, et al. Ovarian steroid and cytokine modulation of human endometrial angiogenesis. Hum Reprod 2000;15(Suppl 3):67-77.

26 Masood R, Cai J, Zheng T, et al. Vascular endothelial growth factor (VEGF) is an autocrine growth factor for VEGF receptor-positive human tumors. Blood 2001; 98:1904-1913.

27 Price DJ, Miralem T, Jiang S, et al. Role of vascular endothelial growth factor in the stimulation of cellular invasion and signaling of breast cancer cells. Cell Growth Differ 2001;12:129-135.

28 Verstovsek S, Lunin S, Kantarjian H, et al. Clinical relevance of VEGF receptors 1 and 2 in patients with chronic myelogenous leukemia. Leuk Res 2003;27: 661-669.

29 Jackson MW, Roberts JS, Heckford SE, et al. A potential autocrine role for vascular endothelial growth factor in prostate cancer. Cancer Res 2002;62:854-859.

30 Huh JI, Calvo A, Stafford J, et al. Inhibition of VEGF receptors significantly impairs mammary cancer growth in C3(1)/Tag transgenic mice through antiangiogenic and non-antiangiogenic mechanisms. Oncogene 2005;24:790-800.

31 Heidenreich R, Machein M, Nicolaus A, et al. Inhibition of solid tumor growth by gene transfer of VEGF receptor-1 mutants. Int J Cancer 2004;111:348-357.

32 Santos SC, Dias S. Internal and external autocrine VEGF/KDR loops regulate survival of subsets of acute leukemia through distinct signaling pathways. Blood 2004;103:3883-3889.

33 Baek JH, Jang JE, Kang CM, et al. Hypoxia-induced VEGF enhances tumor survivability via suppression of serum deprivation-induced apoptosis. Oncogene 2000;19:4621-4631.

34 Gerber HP, Condorelli F, Park J, et al. Differential transcriptional regulation of the two vascular endothelial growth factor receptor genes. Flt-1, but not Flk-1/ KDR, is up-regulated by hypoxia. J Biol Chem 1997; 272:23659-23667.

35 Waltenberger J, Mayr U, Pentz S, et al. Functional upregulation of the vascular endothelial growth factor receptor KDR by hypoxia. Circulation 1996;94:16471654 .

36 Rissanen TT, Vajanto I, Hiltunen MO, et al. Expression of vascular endothelial growth factor and vascular endothelial growth factor receptor-2 (KDR/Flk-1) in ischemic skeletal muscle and its regeneration. Am J Pathol 2002;160:1393-1403.

37 Ottino P, Finley J, Rojo E, et al. Hypoxia activates matrix metalloproteinase expression and the VEGF system in monkey choroid-retinal endothelial cells: involvement of cytosolic phospholipase A2 activity. Mol Vis 2004;10:341-350.

38 Williams CC, Allison JG, Vidal GA, et al. The ERBB4/ HER4 receptor tyrosine kinase regulates gene expression by functioning as a STAT5A nuclear chaperone. J Cell Biol 2004;167:469-478. 